\title{
Resolving Taxonomy and Historic Distribution for Conservation of Rare Great Plains Fishes: Hybognathus (Teleostei: Cyprinidae) in Eastern Colorado Basins
}

\author{
Julie A. Scheurer, Kevin R. Bestgen, and Kurt D. Fausch
}

\begin{abstract}
Similar morphology and confused historical taxonomy of Hybognathus hankinsoni (brassy minnow) and Hybognathus placitus (plains minnow) have made determination of their historic distributions and conservation status unclear in eastern Colorado basins. We developed logistic regression models from morphometric measurements to predict species identity of Hybognathus collections from Colorado and adjacent counties ( $n=1154$ specimens in 134 lots). A model based on orbit diameter, standard length, and eye position correctly predicted $98 \%$ of the specimens examined and $100 \%$ of the museum lots. Hybognathus hankinsoni have larger eyes centered on a horizontal line through the tip of the snout, whereas $\boldsymbol{H}$. placitus have smaller eyes centered above the tip of the snout. The two species were historically sympatric in the Platte, Republican, and Smoky Hill River basins, whereas $H$. placitus was allopatric in the Arkansas River basin. The taxonomic characters defined here will allow accurate identification of future collections to determine the status of these native fishes.
\end{abstract}

$\mathrm{N}$ ATIVE fishes of the Great Plains are well known for their tolerance of harsh physicochemical conditions, including floods, droughts, high water temperatures, and low dissolved oxygen concentrations (Matthews, 1988). Despite this tolerance, distributions of a large number of taxa have declined in recent decades. Four fish species endemic to the Great Plains region are listed as threatened or endangered under the Endangered Species Act (Notropis girardi, Noturus topeka, Noturus placidus, Scaphirhynchus albus), and one is a candidate for federal listing (Etheostoma cragini; http://endangered.fws.gov). Many other wide-ranging native fishes of the Great Plains have been extirpated or are in decline throughout much of the western part of their range (Rabeni, 1996; Fausch and Bestgen, 1997). For example, in Colorado, six of 38 native plains species are known to have been extirpated since the first fish collections were made in the late 1800s (Anguilla rostrata, Nocomis bigutattus, Notropis heterolepis, N. girardi, Macrhybopsis tetranema, Stizostedion spp.), and an additional 13 species are listed by the state as endangered, threatened, or of special concern (T. Nesler, Colorado Division of Wildlife, pers. comm.). Therefore, half of the native taxa have declined or been lost. Identifying the historic distributions of these declining species is necessary to guide conservation efforts but is often hampered by two main problems. First, few early collections exist, and most of these were made after habitats were already altered, some native species were extirpated, and nonnative species were introduced. For example, fish collections are known from only 12 locations before 1900 in the Great Plains portion of eastern Colorado (Fausch and Bestgen, 1997), yet diversion of water for irrigation was well developed by the $1860 \mathrm{~s}$. As a result, the historic distributions of fishes described only in early reports, such as walleye or sauger (Stizostedion spp.) from the South Platte River and speckled chub (Macrhybopsis tetranema; formerly Macrhybopsis aestivalis tetranemus) from the Arkansas River are not fully known. Even their identity cannot be verified because no museum specimens were preserved before these species were extirpated from the state (Fausch and Bestgen, 1997; Eisenhour, 1999; Luttrell et al., 1999).

A second main problem is that identification of some taxa is difficult, resulting in inaccurate field surveys. Moreover, the historical taxonomy may be confused so that even the identity of museum specimens is unclear. Good examples of this are minnows of the genus Hybognathus in 
basins of eastern Colorado. Species in this taxon are similar morphologically, resulting in considerable taxonomic confusion during the past 150 years (Cook et al., 1992; Bestgen and Propst, 1996). At least 15 species and subspecies have been described (Bestgen and Propst, 1996) of which seven are currently recognized (Robins et al., 1991). In the western Great Plains, three forms, later recognized as Hybognathus hankinsoni (brassy minnow), Hybognathus placitus (plains minnow), and Hybognathus argyritis (western silvery minnow), were all originally considered variants of Hybognathus nuchalis (Mississippi silvery minnow; Ellis, 1914). Based on current classification, $H$. argyritis and $H$. nuchalis do not occur in Colorado (Lee et al., 1980). However, many historic museum collections from the Great Plains of eastern Colorado (e.g., Ellis, 1914) are still identified as $H$. nuchalis, because $H$. hankinsoni was not described until 1929 (Hubbs in Jordan, 1929; Bailey, 1954) and $H$. placitus was not separated from $H$. nuchalis until 1962 (Niazi and Moore, 1962; AlRawi and Cross, 1964).

Surveys during the past $20 \mathrm{yr}$ have suggested that the two Hybognathus species in Colorado are in decline (Propst and Carlson, 1986; T. P. Nesler, R. VanBuren, J. Stafford, and M. Jones, Colorado Division of Wildlife, 1997, unpubl.; T. P. Nesler, C. Bennett, J. Melby, G. Dowler, and M. Jones, Colorado Division of Wildlife, 1999, unpubl.), prompting a listing of $H$. hankinsoni as threatened and $H$. placitus as endangered in Colorado in 1998. However, because of the relatively recent taxonomic clarifications, unreliable taxonomic keys, and lack of museum specimens to confirm many published records, the historic and current distributions of H. hankinsoni and $H$. placitus at the western extent of their range in Colorado are unclear (Fausch and Bestgen, 1997). For example, Ellis (1914) recognized small- and large-eyed forms of $\mathrm{H}$. nuchalis throughout warm water reaches of the South Platte River, but the identity of these early collections and many other extant specimens remains undetermined. Recent field collections may also have been misidentified because existing keys are inadequate to distinguish the two species. Therefore, before natural resource managers can propose conservation measures, better taxonomic characteristics are needed to accurately identify museum specimens and determine historic and current distributions of these taxa.

Two characteristics, the shape of the basioccipital process and the number of scale radii, have often been cited as useful to distinguish among Hybognathus species (e.g., Beckman,
1952; Baxter and Simon, 1970; Pflieger, 1975). Unfortunately, both $H$. hankinsoni and $H$. placitus have narrow, peglike basioccipital processes (Schmidt, 1994; Bestgen and Propst, 1996). Although they differ in relative lengths, the similar shape of the basioccipital process in these two species makes it an unreliable characteristic to use. Numbers of scale radii are among the most common characters used to separate $H$. hankinsoni from $H$. placitus in keys. Hybognathus hankinsoni is most often described as having about 20 faint or weak scale radii of varying lengths (except 17-19 in Bailey, 1954), whereas H. placitus is most often reported to have 10-15 strong radii (except $<20$ in Eddy and Underhill, 1969). However, no published account describes criteria to distinguish faint, weak, or strong radii, nor has the utility of this characteristic been determined.

The goal of our research was to develop a reliable technique to distinguish $H$. hankinsoni from $H$. placitus in western Great Plains watersheds where they are sympatric. Our specific objectives were first to test the utility of scale radii as a key characteristic and then to develop a quantitative model based on taxonomic characteristics to separate the two species. The model and additional qualitative characteristics were then used to identify all available museum specimens of Hybognathus from Colorado and adjacent counties in neighboring states, which allowed clarification of the historic distributions of $H$. hankinsoni and H. placitus in Colorado basins. This work, coupled with ongoing sampling and accurate identification, will help natural resource managers determine how much of their historic range in Colorado these two species currently occupy and where to focus restoration and conservation efforts.

\section{Materials AND Methods}

To determine taxonomic characters that distinguish the two species, material was obtained from locations where they are allopatric ("knowns" hereafter) in Michigan (H. hankinsoni, four locations, $n=81$; see Appendix 1) and New Mexico (H. placitus, Canadian River, $n$ $=51$ ). A suite of characters used in earlier keys and studies (Hubbs and Lagler, 1964; Bestgen and Propst, 1996) was measured, including scale radii.

Scale radii analysis. - The number of radii on 82 scales from 60 fish, 30 of each species from the lots of knowns described above, were counted to determine the utility of this character for separating the two species. Scales were removed 
from the right side of the fish, posterior to the pectoral fin base and above the lateral line (DeVries and Frie, 1996). Scales were cleaned, mounted on glass slides, and viewed under a compound microscope at $30 \times$ and $100 \times$. Distances from the focus to the scale margin were measured at three angles, 45, 90, and 135 degrees from a horizontal line through the focus. Radii were categorized as faint, incomplete, or complete by comparing them to the nearest measured distance. We defined faint radii as those less than $30 \%$ of the nearest measured distance from focus to scale margin, incomplete radii as those $31-67 \%$, and complete radii as those greater than $67 \%$ the distance. To determine variation in scale radii counts within individuals, two scales were read from each of 22 fish, 11 of each species.

Morphometric analysis. - Nine quantitative and three qualitative characters were measured from the 132 specimens of known identity described above to develop a quantitative model to separate the two species. The lectotype of $H$. hankinsoni and four syntypes of $H$. placitus were also measured to test and verify the model. Standard length, head length, pectoral fin length, snout length, orbit diameter, body depth, body width, caudal peduncle depth, and gape width were measured following Hubbs and Lagler (1964). Qualitative characters included snout shape, dorsal fin shape, and eye position. Snout shape and dorsal fin shape were categorized as either rounded or pointed. Eye position referred to the location of the center of the eye relative to a horizontal line through the anterior most tip of the snout and was categorized as either even or above (Fig. 1). Quantitative characters were measured to the nearest $0.1 \mathrm{~mm}$ using digital calipers.

After developing the model based on known specimens, we then obtained all available museum collections of Hybognathus from Colorado and adjacent counties in neighboring states, totaling 1753 fish in 134 lots (see Appendix 1; Scheurer, 2002), for examination and reidentification. Specimens included those from the earliest collections in the state by Jordan (1891) and Juday (1904). All these lots were considered Hybognathus of unknown species identity ("unknowns," hereafter), and 1154 individuals were measured. When collections contained many individuals, a subsample of at least 30 fish of all sizes represented was measured. Damaged, deformed, or poorly preserved fish were excluded. The quantitative model was then used to predict the identity of the unknowns, and additional

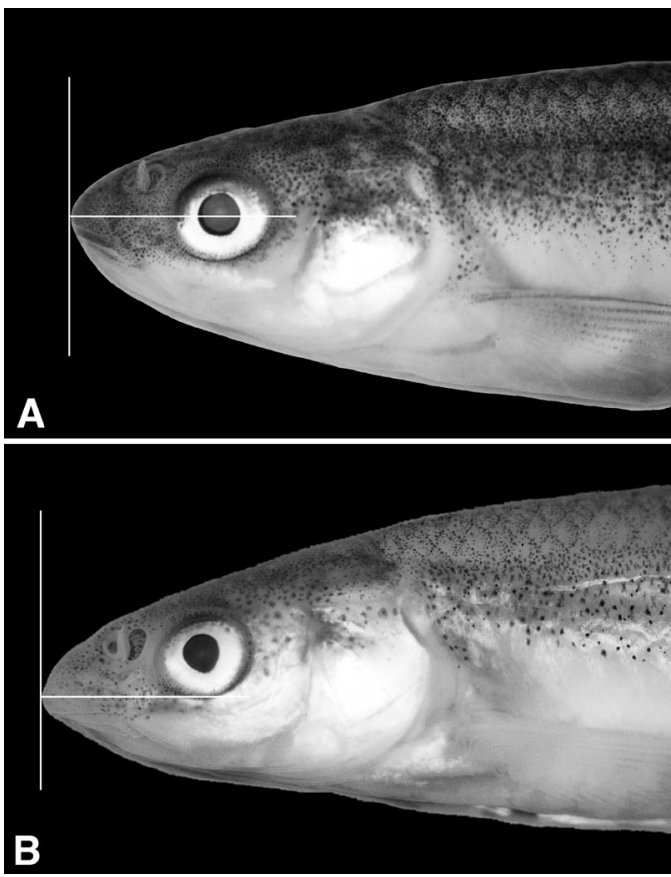

Fig. 1. Eye position characteristic for Hybognathus hankinsoni (A) and Hybognathus placitus (B). Hybognathus hankinsoni typically have larger eyes with the centers even with a horizontal line drawn back from the anteriormost tip of the snout. Hybognathus placitus have smaller eyes with the centers often above this line. Images are by R. E. Zuellig, with permission.

qualitative characters were used to verify model predictions.

Model development and testing.-Logistic regression $\left(\mathrm{SAS} / \mathrm{STAT}^{\circledR}\right.$, PROC LOGISTIC, SAS Institute, Inc., Cary, NC, 2000, unpubl.) was used to develop a model for separating the two species, based on the morphometric independent variables measured from the known specimens. Model selection followed Burnham and Anderson (1998) using Akaike's Information Criterion (AIC) to select the top candidate models. This model selection procedure is based on an information-theoretic approach that is proposed to be superior to traditional hypothesis testing for observational data such as these because it allows comparison of more than two models at once and balances precision and bias (Burnham and Anderson, 1998; Franklin et al., 2000).

Species identity (H. hankinsoni or H. placitus) was first modeled as a function of each of the eight quantitative characters (not including standard length) and each of the three qualitative characters. Additional candidate models were developed using each quantitative charac- 
ter and standard length, the three variables considered a priori to be most diagnostic (orbit diameter, eye position, standard length), and these three variables with various combinations of their two-way interactions. The value of $\mathrm{AIC}_{\mathrm{c}}$ (AIC corrected for small-sample bias), and Akaike weights were calculated and used to rank models (Burnham and Anderson, 1998). Models with the lowest $\mathrm{AIC}_{\mathrm{c}}$ and highest Akaike weight were given the most consideration. An added criterion for selecting the best model was the percentage of known specimens that it classified as the correct species (Hosmer and Lemeshow, 2000).

Once the diagnostic model was developed using known specimens, measurements from the unknown Hybognathus from Colorado were entered in the model to predict their identity. These predictions were verified by the second author using supplemental characters to evaluate the efficacy of the model. With the exception of two large museum lots (UMMZ 135130 and 32241) for which only 30 specimens each could be obtained, all fish in each lot, including those not measured, were examined to ensure that no additional species were present.

The model developed from the known specimens proved only moderately useful for separating all individuals of the two species, so the two best candidate models were refit using the 1154 verified Hybognathus from Colorado to improve predictions. The identity of the type specimens we examined was predicted to validate each model. These models were also tested using cross-validation (Hosmer and Lemeshow, 2000:186). The data were randomly ordered and divided into 10 equal sets. Ten separate models were fit using nine of the 10 datasets, leaving out a different set each time. The data excluded were then used to test each model. The average percentage of the specimens classified correctly was used as a criterion to judge each model.

\section{RESUlts}

Scale radii.-Scale radii were not useful for distinguishing between $H$. placitus and $H$. hankinsoni. Several sources stated that $H$. hankinsoni have about 20 weak radii, which we assumed included either complete plus incomplete radii or the total of all three categories. However, the mean number of total radii for $H$. hankinsoni from this analysis was 17 (range 8-27). More than half of the 30 fish analyzed would be misidentified as $H$. placitus based on the most conservative criterion for $H$. hankinsoni of having 17 or more total radii (Bailey, 1954), and more

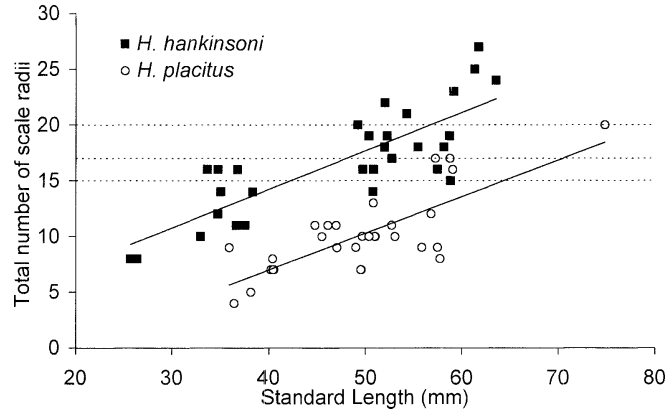

Fig. 2. Total number of scale radii (faint, incomplete, and complete) as a function of standard length for Hybognathus hankinsoni (filled squares) and Hybognathus placitus (open circles). Regression lines are shown for each species. Horizontal dashed lines indicate commonly used criteria for separating the two species. Hybognathus hankinsoni was reported to have 17 to 19 radii in the original full description (Bailey, 1954) and about 20 radii in subsequent keys. Hybognathus placitus was described as having 10 to 15 radii in most keys.

than $75 \%$ would be misidentified based on the most common criterion of 20 or more total radii (Fig. 2). Even higher proportions would be misidentified based on complete plus incomplete radii. In contrast, although $H$. placitus averaged 10 total radii (range 4-20), four of 30 would be misidentified as $H$. hankinsoni based on the most common criterion of 15 or fewer total radii (e.g., Baxter and Simon, 1970). In addition to often misidentifying the two species, the number of scale radii increased with standard length for both $(P<0.001)$. As a result, only $H$. hankinsoni $>60 \mathrm{~mm}$ and $H$. placitus $<$ $55 \mathrm{~mm}$ would be consistently identified correctly.

The number of scale radii also differed between scales from the same fish, further confounding use of this characteristic. Ten of $11 \mathrm{H}$. hankinsoni and five of $11 \mathrm{H}$. placitus had different numbers of total radii on two scales. Using a criterion of 17 or more total radii for $H$. hankinsoni, only three of 11 would have been correctly identified using either scale, the rest being misidentified based on one or both scales (see Scheurer, 2002). Similarly, using a criterion of 15 or fewer total radii for $H$. placitus, only seven of 11 would have been correctly identified based on either scale.

Model based on known specimens. - Logistic regression analysis revealed that the best single quantitative variable for distinguishing between the known $H$. hankinsoni and $H$. placitus was orbit diameter. Hybognathus hankinsoni of a given length 


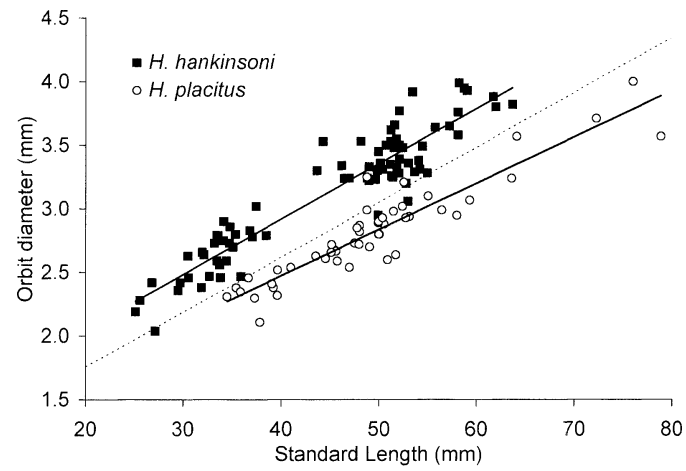

Fig. 3. Orbit diameter as a function of standard length for the 132 known specimens. Solid lines show regression lines for Hybognathus hankinsoni $\left(r^{2}=0.88\right.$, $P<0.001)$ and Hybognathus placitus $\left(r^{2}=0.86, P<\right.$ $0.001)$. Dashed line is the $50 \%$ probability line $(y=$ $0.0431 x+0.8951)$ predicted from logistic regression. Fish represented by points above the line are predicted to be $H$. hankinsoni, whereas those below are predicted to be $H$. placitus.

had a larger orbit diameter than $H$. placitus, and orbit diameter also increased allometrically with standard length for both species $(P<0.001$ for both; Fig. 3). The model based on these two characteristics had the lowest $\mathrm{AIC}_{\mathrm{c}}$ value (41.73), accounted for a high proportion of the Akaike weight of the 19 models with valid parameter estimates $(0.69$; weights sum to 1.0$)$, and correctly classified $96 \%$ of the known specimens. In fact, only one other model, based on standard length, orbit diameter, and their interaction, received any support $\left(\mathrm{AIC}_{\mathrm{c}}=43.35\right)$ and accounted for nearly all the remainder of the Akaike weight (0.31). Therefore, there was no support for including any of the other variables and the model based on orbit diameter and standard length was selected as the best model for predictions (Table $1)$. The model was validated with the type specimens, and correctly predicted the identities of the lectotype of $H$. hankinsoni (UMMZ 84266) and four syntypes of $H$. placitus (USNM 89 [ $n=$ 3], MCZ $1789[n=1])$.

The two-variable equation developed from the knowns for predicting species identity is

$P($ H. hankinsoni $)$

$$
=\frac{\exp (-16.8465-0.8123 S L+18.8391 O D)}{1+\exp (-16.8465-0.8123 S L+18.8391 O D)},
$$

where $P=$ probability of an unknown fish being $H$. hankinsoni, $S L=$ standard length $(\mathrm{mm})$, and $O D=$ orbit diameter $(\mathrm{mm})$. If $P>0.50$, the fish is predicted to be $H$. hankinsoni, whereas if $P<$ 0.50 , the fish is predicted to be $H$. placitus (Fig. $3)$.

Eye position was also a useful qualitative variable for distinguishing the two species. All of the known $H$. hankinsoni had the even eye position, whereas $88 \%$ of the known $H$. placitus had the above eye position (Fig. 1). However, this variable could not be included in models because there was no variation in eye position of the known $H$. hankinsoni so valid maximum likelihood parameter estimates could not be calculated.

Predictions of unknown specimens and additional models. - Of 1154 unknown fish measured and verified, $78 \%$ were predicted by the model to be the correct species. Of the $212 \mathrm{H}$. placitus, species identities of 210 (99\%) were correctly predicted, but species identities of only $73 \%$ of the $942 \mathrm{H}$. hankinsoni were predicted correctly. Of the 257 incorrectly predicted specimens, 255 were $H$. hankinsoni with smaller relative orbit di-

Table 1. Maximum Likelihood Estimates of Intercept and Slope Parameters from Logistic Regression For the Best Model Based on the 132 Known Specimens and the Two Candidate Models Based on the 1154 Unknown Specimens to PREDict Hybognathus SPECIES IDENTITY. Models predict the probability that an unknown specimen is $H$. hankinsoni. Coefficients for the eye position parameter are 0 for even and 1 for above.

Standard errors of parameters are in parentheses.

\begin{tabular}{lcccc}
\hline \multicolumn{1}{c}{ Model } & Intercept & $\begin{array}{c}\text { Standard } \\
\text { length }\end{array}$ & $\begin{array}{c}\text { Orbit } \\
\text { diameter }\end{array}$ & $\begin{array}{c}\text { Eye } \\
\text { position }\end{array}$ \\
\hline $\begin{array}{l}\text { Model based on 132 known specimens } \\
\text { Standard length, orbit diameter }\end{array}$ & -16.8465 & -0.8123 & 18.8391 & - \\
& $(4.0462)$ & $(0.1690)$ & $(3.8075)$ & - \\
Model based on 1154 unknown specimens & & & & - \\
$\quad$ Standard length, orbit diameter & -11.8900 & -0.8222 & 18.9196 & - \\
& $(1.7387)$ & $(0.0740)$ & $(1.7511)$ & -5.3898 \\
Standard length, orbit diameter, eye position & -11.3796 & -0.8009 & 18.5823 & $(1.0643)$ \\
& $(2.0969)$ & $(0.0839)$ & $(2.0224)$ & \\
\end{tabular}




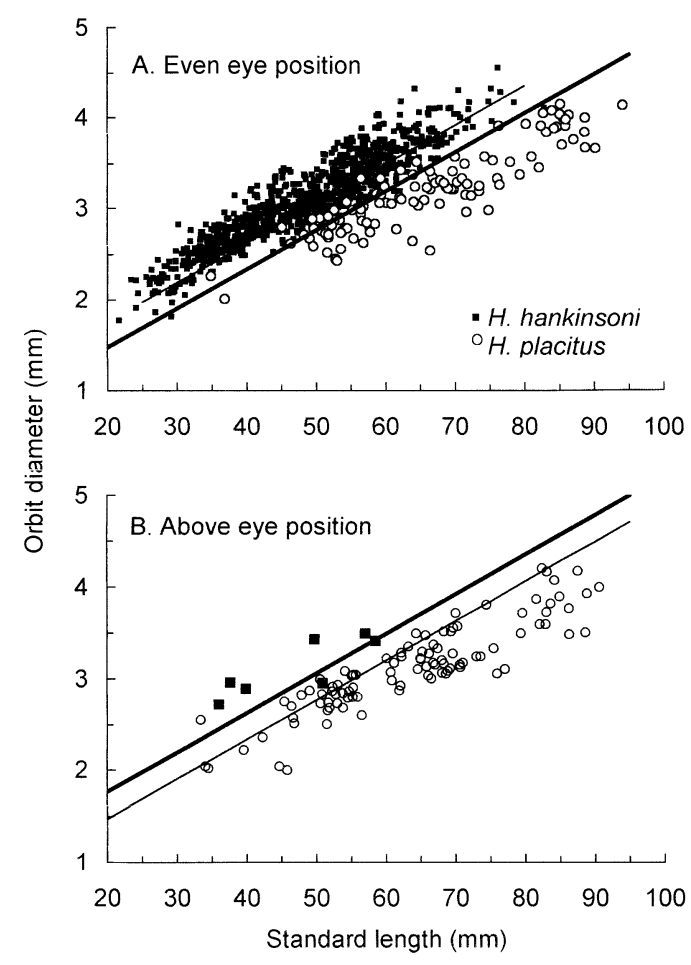

Fig. 4. Orbit diameter as a function of standard length for the 1154 unknown specimens with even eye position (A) and above eye position (B). Decision lines show where the probability of a specimen being Hybognathus hankinsoni is predicted to be $50 \%$. In A, the thin line shows the prediction for the original twovariable model based on 132 known specimens (see Fig. 3), and the thick line shows the prediction for fish with the even eye position for the final three-variable model based on 1154 verified unknowns $(y=$ $0.0431 x+0.6119)$. In $\mathrm{B}$, the thick line shows the prediction from the final three-variable model for fish with the above eye position $(y=0.0431 x+0.9019)$, whereas the thin line shows the prediction for fish with the even eye position for comparison (same as thick line in Fig. 4A).

ameters than the known specimens from Michigan used to build the model (Fig. 4). This model is not useful in Colorado because it predicted that these fish were $H$. placitus, which would lead natural resource managers to overestimate the distribution and abundance of the rarer of the two species. Because of this potential bias, we elected to refit the model using all 1154 verified specimens from the region.

This new two-variable model based on orbit diameter and standard length correctly predicted the identity of $88 \%$ of the $H$. placitus and $99 \%$ of the $H$. hankinsoni verified unknowns (Table 1). This larger sample included seven $H$. hankinsoni with the above eye position, so we also fit a three-variable model including this variable. This model correctly predicted $91 \%$ of the $H$. placitus and $99 \%$ of the H. hankinsoni verified unknowns (Fig. 4). The parameters for intercept, standard length, and orbit diameter were similar between these two- and three-variable models, so the $P=0.50$ decision line for predicting species identity was nearly identical for fish with the even eye position. In contrast, the added parameter for eye position allowed more accurate predictions for specimens with the above eye position. The three-variable model correctly predicted the identity of the most fish and had a lower $\mathrm{AIC}_{\mathrm{c}}$ than the two-variable model (168.98 vs 229.92), so it was selected as the best model. For each model, cross validation resulted in identical estimates for the average percentage of fish correctly classified as those presented above because of the large sample size. Both models correctly classified all the type specimens examined.

The best predictive model, developed from the 1154 Colorado specimens, included standard length, orbit diameter, and eye position (Table 1)

$$
\begin{aligned}
& P(\text { H. hankinsoni }) \\
& =[\exp (-11.3796-0.8009 S L+18.5823 O D \\
& \quad-5.3898 E P)] \\
& \div[1+\exp (-11.3796-0.8009 S L \\
& \quad+18.5823 O D-5.3898 E P)],
\end{aligned}
$$

where $P=$ probability of an unknown fish being H. hankinsoni, $S L=$ standard length $(\mathrm{mm}), O D$ $=$ orbit diameter $(\mathrm{mm})$, and $\mathrm{EP}=$ eye position ( $E P=0$ for even, $E P=1$ for above). If $P>$ 0.50 , the fish is predicted to be $H$. hankinsoni, whereas if $P<0.50$, the fish is predicted to be $H$. placitus. For example, the model predicts that a fish with standard length of $50 \mathrm{~mm}$, orbit diameter of $3.2 \mathrm{~mm}$, and even eye position has nearly a $100 \%$ probability of being $H$. hankinsoni, whereas a fish with an orbit diameter of 2.7 $\mathrm{mm}$, the same standard length, and the above eye position has $<1 \%$ probability of being $H$. hankinsoni (Fig. 4). Therefore, the smaller-eyed fish is predicted to be H. placitus.

Overall, all but 25 of the 1154 unknown specimens $(2 \%)$ were correctly classified by the final model. Moreover, in all lots, the majority ( $\geq$ $67 \%$ ) of fish were predicted to be the correct species (cf. Scheurer, 2002). Eight lots were not measured because of the poor condition of all specimens (range: 1-16 specimens each), but species identity was verified from supplemental characters. Of the 134 lots of unknown Hybog- 
nathus, 33 (25\%) were misidentified or cataloged as species that no longer exist or have been revised. Three of these were mixed lots of $H$. hankinsoni and $H$. placitus, seven lots contained Hybognathus mixed with other taxa, and two lots originally cataloged as $H$. nuchalis contained no Hybognathus.

Taxonomic characteristics of Hybognathus hankinsoni and Hybognathus placitus.-Hybognathus hankinsoni Hubbs was first proposed by Hubbs and Greene (1926) but was not described until Jordan (1929). Bailey (1954) elaborated on this description and designated a lectotype (UMMZ 84266) from the Dead River, a tributary of Lake Superior in Marquette County, Michigan. Earlier names used for $H$. hankinsoni and under which specimens may still be cataloged, include the following.

Hybognathus nuchalis nuchalis Agassiz (in part), 1855; Hendricks, 1950.

Hybognathus nuchalis Agassiz (in part), 1855; Jordan, 1891; Juday, 1904, 1905; Cockerell, 1908; Ellis, 1914.

Hybognathus nubilum (in part), Call, 1887; Meek, 1891; Evermann and Cox, 1896.

Hybognathus nuchale evansi (in part), Eigenmann, 1894; Evermann and Cox, 1896.

Descriptive characters.-Head: Eye large relative to $H$. placitus and about equal to snout length (Fig. 1; mean orbit diameter/snout length $=$ 0.93 , range $0.70-1.38, n=503$ Colorado fish). Horizontal line drawn through the anterior most tip of snout intersects the center of eye in most fish. Mouth terminal and slightly oblique. Head with upturned ventral profile. Basioccipital process peg shaped, shorter than in $H$. placitus. Fleshy snout not visible ventrally. Snout rounded.

Body: Average adult body size $50-70 \mathrm{~mm}$ total length (TL). Maximum size $<100 \mathrm{~mm}$ TL. Dorsal, anal, and pectoral fins rounded (Scheurer, 2002). First ray of dorsal fin shorter than second, giving rounded appearance. Prominent, dark, lateral and predorsal bands of pigment. Margins of scales outlined, especially dorsally. Scales large and prominent. Pectoral fins smaller than in $H$. placitus. Males golden during breeding season.

Hybognathus placitus Girard was first described by Girard (1856). The name $H$. evansi has line priority over $H$. placitus but the first revision by Jordan and Gilbert (1882) used the name $H$. placitus (Al-Rawi and Cross, 1964). Girard designated five syntypes (1858), now cataloged as USNM 89 (3), MCZ 1789 (1), and ANSP 5065
(1), from sluices of the Arkansas River near Dodge City, Ford County, Kansas, collected in 1853 , and a sixth was recently reported (MNHN 351, Gilbert 1998). Earlier names used for $H$. placitus and under which specimens may still be cataloged, include the following.

Hybognathus nuchalis nuchalis Agassiz (in part), 1855; Hendricks, 1950.

Hybognathus nuchalis Agassiz (in part), 1855; Hay, 1887; Ellis, 1914.

Hybognathus evansi Cope, 1865; Girard, 1856, 1858 nomen nudum.

Hybognathus placita Girard; Graham, 1885; Personius and Eddy, 1955.

Hybognathus nubilum (in part), Call, 1887; Meek, 1891; Everman and Cox, 1896.

Hybognathus nuchalis placita, Jordan, 1891; Evermann, 1893.

Hybognathus nuchale, Meek, 1894.

Hybognathus nuchale evansi (in part), Eigenmann, 1894; Everman and Cox, 1896.

Hybognathus churchilli Hildebrand, 1932.

Hybognathus placitus placitus, Johnson, 1942.

Hybognathus placita placita, Beckman, 1952.

Descriptive characters.-Head: Eye smaller than in $H$. hankinsoni and notably less than snout length (Fig. 1; mean orbit diameter $/$ snout length $=$ 0.69 , range $0.52-1.03, n=66$ Colorado fish). Horizontal line through anterior most tip of snout generally crosses below the center of the eye resulting in a decurved anterior dorsal profile. Mouth subterminal and horizontal. Head with flat ventral profile. Peg-shaped basioccipital process, longer than in H. hankinsoni. Fleshy snout visible ventrally. Snout relatively pointed.

Body: Average adult body size 50-90 mm TL. Maximum size $130 \mathrm{~mm}$ TL. Dorsal, anal, and pectoral fins pointed (Scheurer, 2002). First ray of dorsal fin usually longer than second, creating a falcate posterior fin margin. Lateral and predorsal bands of pigment present but not as prominent as in $H$. hankinsoni. Scales more embedded than in $H$. hankinsoni. Dorsal scales not darkly outlined. Pectoral fins large relative to $H$. hankinsoni.

Scott and Crossman (1973) and Becker (1983) provide more detail on descriptive characteristics for H. hankinsoni, and Al-Rawi and Cross (1964) and Niazi and Moore (1962) provide detailed descriptive characteristics for $H$. placitus. Researchers should refer to Eschmeyer (1998) and Gilbert (1998) for a more thorough history of the nomenclature of both species.

Historic distribution. - The correct identification of museum specimens allowed a clear determi- 


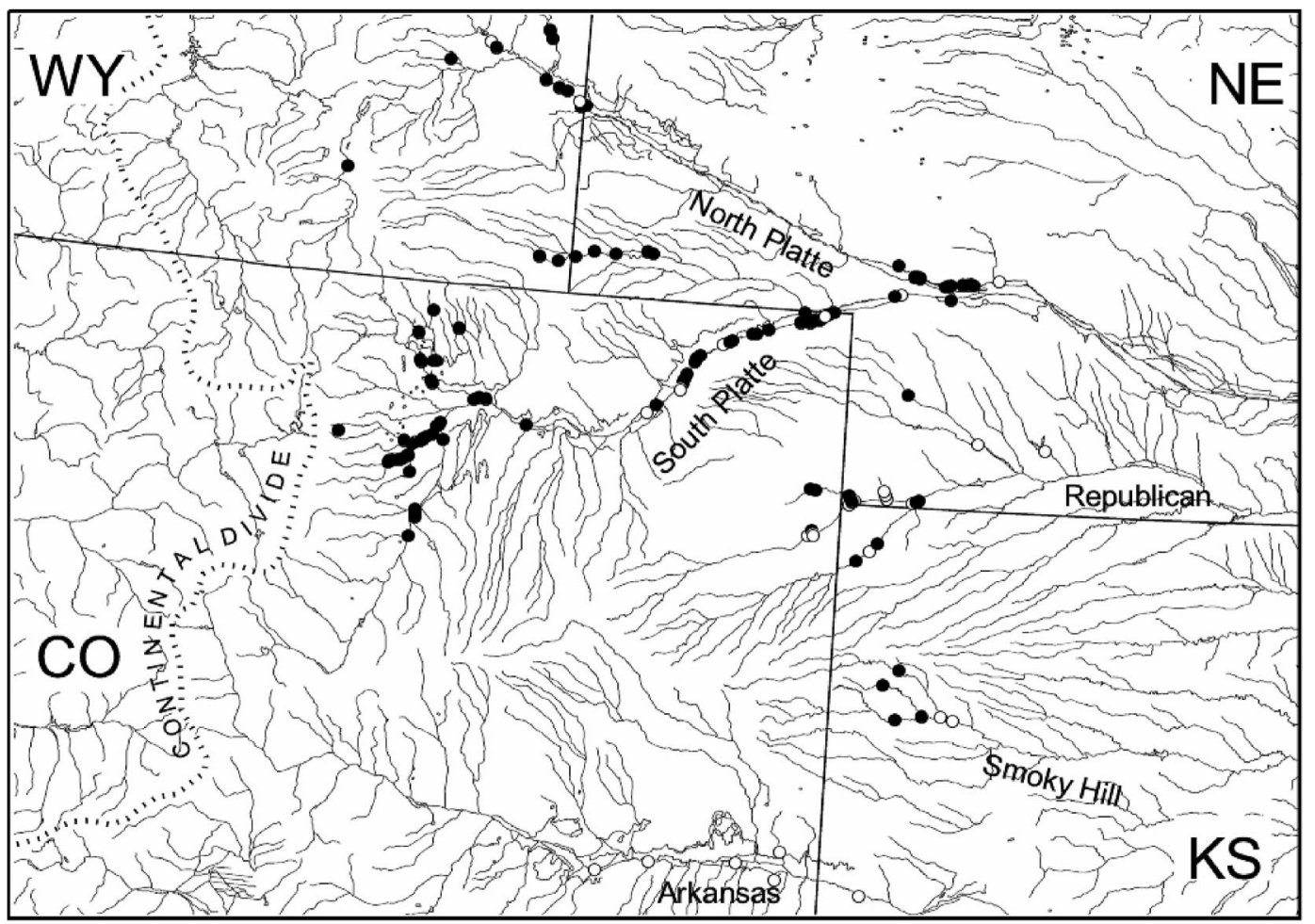

Fig. 5. Historical distribution of Hybognathus hankinsoni and Hybognathus placitus in Colorado and adjacent counties in neighboring states based on verified museum collections (Scheurer, 2002). Closed circles indicate H. hankinsoni and open circles $H$. placitus.

nation of the historical distribution of these two Hybognathus species in Colorado and surrounding states (Fig. 5). Hybognathus hankinsoni was distributed throughout the main stem of the South Platte River, in one of its major plains tributaries in southwestern Nebraska (Lodgepole Creek) and west to its transition-zone tributaries in the foothills of the Rocky Mountains. In the Republican River basin, its distribution extended into the headwater plains tributaries in eastern Colorado. The southwestern extent of its entire distribution was in the headwaters of the Smoky Hill River in the Kansas River basin of western Kansas. Hybognathus hankinsoni has never been recorded or collected from the Arkansas River basin. It was also widely distributed along the North Platte River in Nebraska and into the headwaters in Wyoming. In contrast, $H$. placitus was allopatric in the Arkansas River basin. It occurred in sympatry with $H$. hankinsoni in the Smoky Hill and Republican rivers near their headwaters and in the lower main stems of the South Platte and North Platte Rivers on the plains.

\section{Discussion}

Two characters commonly used to identify Hybognathus species, the shape of the basioccipital process and the number of scale radii, should not be used to separate $H$. hankinsoni and $H$. placitus. The similarity in shape of the basioccipital process between the two species makes it an unreliable characteristic to use by itself. We also do not recommend the continued use of scale radii counts because of strong overlap between the two species, the increase in number of scale radii with standard length, and variation among scales from the same fish. Measuring orbit diameter, standard length, and eye position is not only more reliable for distinguishing the two species but is faster and easier than mounting and reading scales or comparing relative lengths of the basioccipital process, which requires partial dissection.

The logistic regression model with the independent variables orbit diameter, standard length, and eye position fit to the 1154 measured and verified specimens from Colorado and adjacent counties reliably distinguished 
most $H$. hankinsoni from $H$. placitus. This model correctly predicted species identities for $98 \%$ of all individuals and $100 \%$ of the lots based on predictions for the majority of individuals in each lot. When this model is used in conjunction with the recommended supplemental characteristics, all but the most unusual individuals should be correctly identified. This analysis clarified the identities of all museum specimens of Hybognathus collected from the region known to us, $25 \%$ of which were previously misclassified. The proper identification of extant specimens allowed accurate description of the historic distributions of these species in eastern Colorado river basins.

This model will also be a useful diagnostic tool for reliably distinguishing $H$. placitus from $H$. hankinsoni in new collections and will allow their current distribution and status to be determined. The model is based on precise measurements, so proper identification will require preserving voucher specimens for laboratory analysis. It may also be helpful to compare them with other verified collections. Eventually, field biologists may become familiar with the differences between these species allowing identification without using the model. A small percentage of individuals will not fit the key because of individual or clinal variation. Extra care must be taken with small fish because measurement errors will have a proportionately larger effect on the model predictions. All model predictions should be verified using supplemental characteristics such as the shape of the snout, shape of dorsal and anal fins, mouth position, maximum body size, and coloration patterns. This is especially important when identifying fish collected from areas of sympatry and when the model yields borderline predictions (i.e., $P \approx 0.50$ ). This key will be especially helpful for collections from northern Kansas and Missouri northwest to Montana and North Dakota where $H$. hankinsoni and $H$. placitus are sympatric in the upper Missouri, Platte, Republican, and upper Kansas river basins (Burr, 1980; Gilbert, 1980).

Hybognathus hankinsoni in eastern Colorado basins had smaller eyes than those from near the center of their distribution in Michigan. Wells (1978) identified two morphological groups of $H$. hankinsoni, a Great Lakes form and a Missouri River form, that he believed evolved in separate glacial refugia during the Wisconsin glaciation. The Great Lakes form is described as having a larger eye than the Missouri River form, but Wells (1978) did not think taxonomic distinction of the two forms was warranted. According to his hypothesis, the original model based on fish from Michigan describes the
Great Lakes form, whereas the final model based on the Colorado fish describes the Missouri River form. Overall, the final model is most useful, because it can be used to separate the two species where they are sympatric in western Great Plains basins.

The different morphologies of $H$. hankinsoni and $H$. placitus are consistent with adaptations for their preferred habitats. Hybognathus hankinsoni prefer small, clear streams with low velocity (Copes, 1970). These conditions favor larger eyes, more prominent scales, and a more upturned ventral profile. A preference for smaller streams may also limit the maximum body size, and low flow velocity precludes the need for large pectoral fins. In contrast, $H$. placitus prefer medium to large plains rivers (Cross, 1967). Their smaller eyes and more embedded scales may adapt them for turbid water environments. The larger pectoral fins, flatter ventral profile, and larger maximum body size of $H$. placitus also better suit them to the flow conditions encountered in larger streams. The differences in form between $H$. hankinsoni and $H$. placitus also match the patterns of form in relation to zoogeographic dispersal pathways described by Metcalf (1966). He identified a typical body form for fish of northeastern origin, such as $H$. hankinsoni, characterized by a more fusiform body outline, nearly terminal and oblique mouth, and larger eyes. Hybognathus placitus, on the other hand, have a southwestern origin characterized by a decurved anterior dorsal surface, flat ventral surface, inferior, horizontal mouth, and smaller eyes and scales. These patterns fit our observations about the differences between the two species.

The current distribution of these species is believed to be contracting from the western edge of their former range (e.g., T. P. Nesler, R. VanBuren, J. Stafford, and M. Jones, Colorado Division of Wildlife, 1997, unpubl.; T. P. Nesler, C. Bennett, J. Melby, G. Dowler, and M. Jones, 1999, unpubl.; Patton, 1997). However, it is impossible to verify many recent accounts because no voucher specimens exist and the species may have been misidentified in the field. We stress the importance of collecting and preserving voucher specimens for laboratory identification so that precise measurements and comparative assessments of supplemental characters can be obtained. Additionally, properly curated museum specimens are critical for ecologists attempting to determine changes in distribution (Shaffer et al., 1998) and taxonomists resolving future taxonomic conundrums of fishes like $\mathrm{Hy}$ bognathus in Colorado and surrounding states. 


\section{ACKNOWLEDGMENTS}

For specimen loans, we extend our sincere appreciation to D. Catania, J. Clayton, R. Humphrey, S. Jewett, T. Labedz, D. Nelson, C. Ramotnik, K. Rhode, A. Snyder, and D. Snyder. We thank A. Ramey for assistance measuring specimens and scales and R. Zuellig for generously donating his photographic services. D. Anderson and P. Chapman gave valuable statistical advice, and B. Kondratieff, J. Savidge, and two anonymous reviewers gave helpful comments that improved the manuscript. Funding for this research was by grants to KDF from the Colorado Water Resources Research Institute administered by R. Ward and from the Colorado Division of Wildlife administered by T. Nesler.

\section{Literature Cited}

AgASSIZ, L. 1855. Synopsis of the ichthyological fauna of the Pacific slope of North America, chiefly from the collections made by the U.S. Expl. Exped. under the command of Capt. C. Wilkes, with recent additions and comparisons with eastern types. Am. J. Sci. Arts 19:215-231.

Al-Rawi, A. H., AND F. B. Cross. 1964. Variation in the plains minnow, Hybognathus placitus. Trans. Kans. Acad. Sci. 67:154-168.

BAILEY, R. M. 1954. Distribution of the American cyprinid fish Hybognathus hankinsoni with comments on its original description. Copeia 1954:289-291.

BAXter, G. T., AND J. T. SimOn. 1970. Wyoming fishes. Wyoming Game and Fish Department, Cheyenne.

BeCKer, G. C. 1983. Fishes of Wisconsin. Univ. of Wisconsin, Press, Madison.

BeCKMAN, W. C. 1952. Guide to the fishes of Colorado. Univ. of Colorado Museum Leaflet No. 11, Boulder.

Bestgen, K. R., And D. L. Propst. 1996. Redescription, geographic variation, and taxonomic status of Rio Grande silvery minnow, Hybognathus amarus (Girard, 1856). Copeia 1996:41-55.

Burnham, K. P., AND D. R. ANDERson. 1998. Model selection and inference: a practical information-theoretic approach. Springer-Verlag, Inc., New York.

BurR, B. M. 1980. Hybognathus hankinsoni Hubbs, p. 175. In: Atlas of North American freshwater fishes. D. S. Lee, C. R. Gilbert, C. H. Hocutt, R. E. Jenkins, D. E. McAllister, and J. R. Stauffer Jr. (eds.). North Carolina State Museum of Natural History, Raleigh.

CALL, R. E. 1887. Memoranda on a collection of fishes from the Ozark region of Missouri. Proc. Davenport Acad. Nat. Sci. V:73-80.

CoCKERELL, T. D. A. 1908. Fishes of the Rocky Mountain region. Univ. Colo. Stud. 5:159-178.

Cook, J. A., K. R. Bestgen, D. L. Propst, and T. L. YATES. 1992. Allozymic divergence and systematics of the Rio Grande silvery minnow, Hybognathus amarus, (Teleostei: Cyprinidae). Copeia 1992:36-44.

COPE, E. D. 1865. Partial catalogue of the cold-blooded Vertebrata of Michigan. Part I. Proc. Acad. Nat. Sci. Phila. 16:276-285.
Copes, F. A. 1970. A study of the ecology of the native fishes of Sand Creek, Albany County, Wyoming. Unpubl. master's thesis. Univ. of Wyoming, Laramie.

Cross, F. B. 1967. Handbook of the fishes of Kansas. Univ. of Kansas Museum of Natural History Publ. 45, Lawrence.

DeVries, D. R., AND R. V. FRIE. 1996. Determination of age and growth, p. 483-512. In: Fisheries techniques. 2d ed. B. R. Murphy and D. W. Willis (eds.). American Fisheries Society, Bethesda, MD.

EdDy, S., AND J. C. Underhill. 1969. How to know the freshwater fishes. Wm. C. Brown Co. Publ., Dubuque, IA.

Eigenmann, C. H. 1894. Results of explorations in western Canada and the northwestern United States. Bull. U.S. Fish Comm. 14:101-132.

EISENhour, D. J. 1999. Systematics of Macrhybopsis tetranema (Cypriniformes: Cyprinidae). Copeia 1999: 969-980.

Ellis, M. M. 1914. Fishes of Colorado. Univ. Colo. Stud. 11:1-136.

EschmeYer, W. N. 1998. Catalog of fishes. Vols. 1-3. California Academy of Sciences, Anaheim.

Evermann, B. W. 1893. The ichthyologic features of the Black Hills. Proc. Indiana Acad. Sci. 1892(1893):73-78.

- AND U. O. Cox. 1896. Report upon the fishes of the Missouri River basin. Rept. U.S. Fish Comm. 1894 20:325-429.

Fausch, K. D., AND K. R. Bestgen. 1997. Ecology of fishes indigenous to the central and southwestern Great Plains, p. 131-166. In: Ecology and conservation of Great Plains vertebrates. F. L. Knopf and F. B. Samson (eds.). Springer-Verlag, New York.

Franklin, A. B., D. R. Anderson, R. J. Gutierrez, AND K. P. Burnhan. 2000. Climate, habitat quality, and fitness in northern spotted owl populations in northwestern California. Ecol. Monogr. 70:539-590.

GILBERT, C. R. 1980. Hybognathus placitus Girard, p. 178. In: Atlas of North American freshwater fishes. D. S. Lee, C. R. Gilbert, C. H. Hocutt, R. E. Jenkins, D. E. McAllister, and J. R. Stauffer Jr. (eds.). North Carolina State Museum of Natural History, Raleigh.

- 1998. Type catalogue of recent and fossil North American freshwater fishes: families Cyprinidae, Catostomidae, Ictaluridae, Centrarchidae and Elassomatidae. Florida Museum of Natural History, Spec. Publ. 1, Gainesville.

GIRARD, C. 1856. Researches upon the cyprinoid fishes inhabitating [sic] the fresh waters of the United States of America, west of the Mississippi Valley, from specimens in the museum of the Smithsonian Institution. Proc. Acad. Nat. Sci. Phila. 8:165-213.

1858. Fishes. In: Explorations and surveys for a railroad route from the Mississippi River to the Pacific Ocean. War Dept., Washington, DC.

Graham, I. D. 1885. Preliminary list of Kansas fishes. Trans. Kans. Acad. Sci. 9:69-78.

HaY, O. P. 1887. A contribution to the knowledge of the fishes of Kansas. Proc. U. S. Nat. Mus. 10:242253.

Hendricks, L. J. 1950. The fishes of Boulder County, Colorado. Unpubl. master's thesis. Univ. of Colorado, Boulder. 
Hildebrand, S. F. 1932. On a new cyprinoid from South Dakota. J. Wash. Acad. Sci. 22:257-260.

Hosmer, D. W., AND S. Lemeshow. 2000. Applied logistic regression. $2 \mathrm{~d}$ ed. John Wiley and Sons, Inc., New York.

Hubbs, C. L., And C. W. Greene. 1926. Further notes on the fishes of the Great Lakes and tributary waters. Univ. Mich. Mus. Zool., Misc. Publ. 15:1-77.

—, AND K. F. Lagler. 1964. Fishes of the Great Lakes region. Cranbrook Press, Bloomfield Hills, MI.

Johnson, R. E. 1942. The distribution of Nebraska fishes. Unpubl. Ph.D. diss., Univ. of Michigan, Ann Arbor.

JORDAN, D. S. 1891. Report of explorations in Colorado and Utah during the summer of 1889 , with an account of the fishes found in each of the river basins examined. Bull. U.S. Fish Comm. 9:1-40.

-1929. Manual of the vertebrate animals of the northeastern United States. 13th ed. World Book Co., New York.

—, AND C. H. Gilbert. 1882. Synopsis of the fishes of North America. Bulletin of the United States National Museum 47, Washington, DC.

JUDAY, C. 1904. Fishes of Boulder County, Colorado. Univ. Colo. Stud. 2:113-114.

- 1905. List of fishes collected in Boulder County, Colorado, with description of a new species of Leuciscus. Bull. Bur. Fish. 9:225-227.

Lee, D. S., C. R. Gilbert, C. H. Hocutt, R. E. Jenkins, D. E. MCAllister, And J. R. Stauffer JR. 1980. Atlas of North American freshwater fishes. North Carolina State Museum of Natural History, Raleigh.

Leviton, A. E., R. H. Gibbs JR., E. Heal, and C. E. DAwSON. 1985. Standards in ichthyology and herpetology. Part 1. Standard symbolic codes for institutional resource collections in herpetology and ichthyology. Copeia 1985:802-832.

Luttrell, G. R., A. A. Echelle, W. L. Fisher, and D. J. Eisenhour. 1999. Declining status of two species of the Macrhybopsis aestivalis complex (Teleostei: Cyprinidae) in the Arkansas River basin and related effects of reservoirs as barriers to dispersal. Ibid. 1999:981-989.

Matthews, W. J. 1988. North American prairie streams as systems for ecological study. J. N. Am. Benth. Soc. 7:387-409.

MeeK, S. E. 1891. Report of explorations made in Missouri and Arkansas during 1889, with an account of the fishes observed in each of the river basins examined. Bull. U.S. Fish Comm. 9:113-141.

. 1894. Notes on the fishes of western Iowa and eastern Nebraska. Ibid. 14:133-138.

Metcalf, A. L. 1966. Fishes of the Kansas River system in relation to zoogeography of the Great Plains. Univ. Kans. Publ., Mus. Nat. Hist. 17:23-189.

NiAZI, A. D., AND G. A. MoORE. 1962. The Weberian apparatus of Hybognathus placitus and H. nuchalis (Cyprinidae). Southwest. Nat. 7:41-50.

Patton, T. M. 1997. Distribution and status of fishes in the Missouri River drainage in Wyoming: implications for selecting conservation areas. Unpubl. Ph.D. diss., Univ. of Wyoming, Laramie.
Personius, R. G., ANd S. Eddy. 1955. Fishes of the Little Missouri River. Copeia 1955:41-43.

Pflieger, W. L. 1975. The fishes of Missouri. Missouri Department of Conservation, Columbia.

Propst, D. L., AND C. A. Carlson. 1986. The distribution and status of warmwater fishes in the Platte River drainage, Colorado. Southwest. Nat. 31:149-167.

Rabeni, C. F. 1996. Prairie legacies: fish and aquatic resources, p. 111-124. In: Prairie conservation: preserving North America's most endangered ecosystem. F. B. Samson and F. L. Knopf (eds.). Island Press, Covelo, CA.

Robins, C. R., R. M. BAIley, C. E. Bond, J. R. BrookER, E. A. Lachner, R. N. Lea, And W. B. SCOtt. 1991. Common and scientific names of fishes from the United States and Canada. American Fisheries Society, Spec. Publ. 20. Bethesda, MD.

Scheurer, J. A. 2002. Systematics and ecology of brassy minnow (Hybognathus hankinsoni) in Colorado. Unpubl. master's thesis, Colorado State Univ., Fort Collins.

SCHMidT, T. R. 1994. Phylogenetic relationships of the genus Hybognathus (Teleostei: Cyprinidae). Copeia 1994:622-630.

ScotT, W. B., And E. J. Crossman. 1973. Freshwater fishes of Canada. Fisheries Research Board of Canada, Ottawa, ON, Canada.

Shaffer, H. B., R. N. Fisher, And C. Davidson. 1998. The role of natural history collections in documenting species declines. Trends Ecol. Evol. 13:27-30.

Wells, A. W. 1978. Systematics, variation, and zoogeography of two North American cyprinid fishes. Unpubl. Ph.D. diss., Univ. of Alberta, Edmonton, Canada.

DEPARTMENT OF Fishery AND Wildlife Biology, Colorado State University, Fort Collins, Colorado 80523. Present addresses: (JAS) National Marine Fisheries Service, ManCHESter Research Station, 7305 Beach Drive EAST, PORT ORCHARD, WASHINGTON 98366; AND (KRB) LARVAL FISH LABORATORY, COLORado State University, Fort Collins, ColoRADO 80523. E-mail: (JAS) julie.scheurer@ noaa.gov. Send reprint requests to JAS. Submitted: 29 January 2002. Accepted: 3 Aug. 2002. Section editor: S. A. Schaefer.

\section{APPENDIX 1}

Material examined.-Museum lots are listed below according to their current museum classification. Institutional abbreviations are as listed in Leviton et al. (1985). Museum lots from the Biological Surveys Division of the U.S. Department of the Interior (BSFC) are deposited in the Biological Surveys Collections in the Museum of Southwestern Biology, Albuquerque, New Mexico.

Hybognathus hankinsoni, Colorado (CO): South Platte R.; CAS $100903(n=5)$; LFL uncataloged ( $n$ $=84)$, KU $4795(n=3)$, KU $4668(n=3)$; UMMZ $86895(n=1)$, BSFC $906(n=1)$, BSFC $1015(n=$ 
1), BSFC $1125(n=1)$, BSFC $1923(n=2)$, BSFC $2176(n=12)$, BSFC $2311(n=2)$, BSFC $2420(n=$ $6)$, BSFC $2888(n=13)$, BSFC $2897(n=2)$, BSFC $2903(n=8)$, BSFC $2919(n=12)$, BSFC $2929(n=$ $11)$, BSFC $2940(n=15)$, BSFC $2959(n=5)$, BSFC $2986(n=4)$, BSFC $2999(n=1)$, BSFC $3009(n=$ $6)$, BSFC $3032(n=2)$, BSFC $3086(n=2)$, BSFC $3106(n=1)$, BSFC $3256(n=169)$, BSFC $3292(n$ $=53)$, BSFC $3400(n=6)$, BSFC $3705(n=6)$, BSFC $3707(n=5)$; Lodgepole Ck.; UMMZ $66155(n=4)$; Lonetree Ck.; BSFC $3409(n=17)$; Cache la Poudre R.; BSFC $955(n=11)$, KU $4782(n=32)$, KU 5565 $(n=27)$; Spottlewood Ck.; BSFC $2617(n=1)$; Larimer-Weld Canal; MSB $4647(n=3)$; MSB $4806(n=$ 33); St. Vrain Ck.; BSFC $853(n=5)$, BSFC $2114(n$ $=6)$, BSFC $2395(n=1)$, BSFC $2409(n=1)$, BSFC $2754(n=5)$, BSFC $3410(n=10)$; Boulder Ck.; BSFC $1072(n=1)$, MSB $1164(n=1)$; UMMZ $66159(n$ = 5); Buffalo Ck.; MSB $1112(n=1)$; Republican R.; UMMZ $66144(n=5)$; Kansas (KS): Republican R.; KU $17283(n=6)$, KU $4043(n=1)$; Smoky Hill R.; KU $3788(n=4)$; USNM $38237(n=2)$; South Fk. Smoky Hill R.; UMMZ $160450(n=1)$; Turtle Ck.; UMMZ $160462(n=1)$; Michigan (MI): Dead R.; UMMZ $84266(n=1)$; Rifle R.; UMMZ $229833(n=$ 28); Tamarack Ck.; UMMZ $232820(n=15)$; Carp Lake R.; UMMZ 234967 ( $n=22)$; Railroad Ck.; UMMZ $234993(n=16)$; Nebraska (NE): North Platte R.; KU $4848(n=21)$; ZM $2445(n=6)$; ZM $2446(n$ $=4)$; ZM $2503(n=1)$; ZM $2627(n=5)$; ZM 5387 $(n=1)$; ZM $5993(n=1)$; ZM $6108(n=6)$; ZM $6114(n=88)$; ZM $6155(n=38) ; \mathrm{ZM} 6164(n=1)$; ZM $7015(n=9)$; ZM $7120(n=2)$; UMMZ 134430 $(n=1)$; UMMZ $134452(n=4)$; Lonergran Ck.; UMMZ $134398(n=7)$; South Platte R.; UMMZ $134390(n=4)$; Lodgepole Ck.; KU $2013(n=153)$; ZM $6438(n=3)$; UMMZ $132241(n=30$ of 319$)$; UMMZ $135161(n=41)$; Republican R.; UMMZ $134361(n=7)$; Arikaree R.; KU $2680(n=5)$; Wyoming (WY): South Platte R.; UMMZ $114653(n=9)$;
Muddy Ck.; UMMZ $162348(n=8)$; North Platte R.; BSFC $1218(n=10)$, UMMZ $104079(n=3)$; UMMZ $113500(n=2)$; UMMZ $134811(n=5)$; UMMZ $169127(n=16)$; Rawhide Ck.; UMMZ $104069(n=$ 5); UMMZ $115020(n=4)$; Laramie R.; KU $4821(n$ $=3)$, KU $4808(n=3)$.

Hybognathus placitus, Colorado (CO): South Platte R.; BSFC $3255(n=5)$, BSFC $3708(n=1)$; Republican R.; Arikaree R.; UMMZ $66144(n=2)$; Purgatoire R.; KU $4744(n=2)$; Arkansas R.; KU 4735 ( = 31); UMMZ $94934(n=16)$; Kansas (KS): Republican R.; UMMZ $122120(n=1)$; Smoky Hill R.; UMMZ $122144(n=1)$; UMMZ $160466(n=9)$; Arkansas R.; USNM $89(n=3)$; MCZ $1789(n=1)$; UMMZ $160439(n=8)$; Nebraska (NE): South Platte R.; UMMZ $134389(n=7)$; Republican R.; ZM 9311 $(n=2)$; ZM $9452(n=7)$; ZM $9578(n=2)$; UMMZ $134349(n=32)$; UMMZ $134360(n=2)$; UMMZ $134370(n=1)$; Red Willow Ck.; UMMZ $135109(n$ = 1); Frenchman Ck.; UMMZ $135119(n=57)$; North Fork Republican R.; ZM $8699(n=2)$; Arikaree R.; UMMZ $135130(n=30$ of 374); UMMZ $145017(n=$ 37); North Platte R.; UMMZ $135249(n=1)$; New Mexico (NM): Canadian R.; LFL $43030(n=51)$; Wyoming (WY): North Platte R.; UMMZ $104061(n=3)$; UMMZ $134812(n=2)$.

Hybognathus nuchalis, Colorado (CO): South Platte R.; UCM $342(n=9)$; USNM $41721(n=3)$; Lodgepole Ck.; UCM $343(n=34)$; Saint Vrain R.; UCM 17 $(n=1)$; Boulder Ck.; CAS $68226(n=3)$; UCM 24 $(n=3)$; UCM $344(n=27)$; UCM $6266(n=68)$; UCM $6278(n=38)$; UCM $6878(n=1)$; Rock Ck.; UCM $6324(n=7)$; Bear Ck.; CAS $72788(n=10)$; North Fork Republican R.; UCM $345(n=127)$; Arikaree R.; UCM $6212(n=38)$; Black Wolf Ck.; UCM $6224(n=1)$; Arkansas R.; UCM $347(n=2)$; USNM $41708(n=1)$; Kansas (KS): Republican R.; USNM $249860(n=1)$.

Hybognathus argyritis, Colorado (CO): South Platte R.; BSFC $3180(n=2)$. 